\title{
Monok, István and Edina Zvara, Esterhasiana Biblioteca: A gyüjtemény története és könyvanyagának rekonstrukciója [Esterhasiana Bibliotheca: History of the Collection and Reconstruction of its Stocks]
}

Budapest: Magyar Tudományos Akadémia Könyvtár és Információs Központ; Kossuth Kiadó, 2020. 584 pp.

\section{Jakab Kárpáti}

Independent researcher; jakabkarpati@gmail.com

Pál Esterházy (1635-1713) was a Hungarian aristocrat who served as the Palatine of the Kingdom of Hungary between 1681 and 1713. The huge volume entitled Esterhasiana Biblioteca, written by István Monok and Edina Zvara, focuses on the library of Pál Esterházy and his closer family. Monok and Zvara’s work does not aim to analyze the erudition of the Esterházy family, but tries to give a deep insight into the history and the gradual enlargement of their library. The library has a ragged history characterized by various difficult periods and gripping human destinies. The Introduction to the book deals with the life of Pál Esterházy, followed by the history of the library. The bulk of the book looks at the sources that are still available in the stocks of the so-called Esterhasiana Biblioteca, a name given by Pál Esterházy in his testament. The great majority of the stocks of the original library are still available. Most of the books are in the small city of Kismarton (known as Eisenstadt) in Austria, however, some are in other Slovakian, Austrian and Russian collections.

We learn from the Introduction that after becoming the head of the family, Pál Esterházy bought several castles and huge estates, and thereby inherited a great responsibility. In addition to enriching the family's treasury and art gallery, Pál intended to enrich their library as well. Not only did he buy new pieces of books, but he also had a vision for cultural policy. As a politician, Pál Esterházy wanted to contribute to enhancing literacy in his country. One of the main elements of his mission was to popularize the Madonna cult in Hungary. Thus, in his literary work, he dealt with Madonna shrines. Financially, he contributed to publishing dozens 
of books. As a lover of music, he published a famous collection of church music entitled Harmonia Caelestis.

Similarly to other aristocratic families, Esterházy paid great attention to his family's history. Seen as one of the major typographic achievements of the seventeenth century, his book entitled Trophaeum domus Estorasianae (1700) on the glorious history of the Esterházys was published in Vienna. He also tried to research the Hungarian people's past in order to place the Kingdom of Hungary into Europe as an independent entity, rather than merely a part of the Habsburg Empire. The Introduction concludes with the assumption that Esterházy's love of art and huge fortune were essential components for grounding the internationally known Esterhasiana Biblioteca.

In the chapter on the "History of the library", the authors introduce how the stocks of the library were expanded. The original collection was in the family's castle in the town of Fraknó. When during the life of Palatine Pál Esterházy, several new estates and castles were added to the family's properties, the stocks of books from those locations were merged into the Esterházy family's old library.

Later, Pál Esterházy created another library in Kismarton (Eisenstadt today), while maintaining the collection in Fraknó for family use only. As Esterházy's wife, Orsolya Dersffy, was the heir to the huge estate in the town of Lakompak, that collection also passed into the hands of Pál Esterházy. In addition, in 1676 the descendants of János Listi, the bishop of the Hungarian cities of Veszprém and Györ, sold their book collection to Esterházy. In 1862, descendants of the Esterházy family merged the collections originating from various castles in Kismarton. It is estimated that around seventy thousand volumes were involved. After 1756, according to Palatine Pál Esterházy's testament, the collection was given to the local Franciscans. Unfortunately, the monks neglected the Esterhasiana Biblioteca. They did not enrich the collection, did not take care of the volumes, and even mixed the Esterházy collection with their own stocks. Consequently, in 1829 the library was named Bibliotheca Franciscano-Esterházyana.

In 1937, one of the descendants of Palatine Pál Esterházy, Prince Pál Esterházy (1901-1989) took the books from the Franciscans back to the castle in Kismarton. The main reason behind this move seems to have been that he wanted to keep the collection safe in the threatening atmosphere of the impending World War II. In 1937, the librarian János Hárich did the stock-taking of the books. He stamped the "Bibliotheca C. P. Esterházy" signal into each volume and printed an inventory and shelf number into each of them. In April 1945, the castle in Kismarton was occupied by Soviet soldiers, and it is estimated that around two thousand books were then taken to the Soviet Union, among others, to the Margarita Rudomino All-Russia State Library for Foreign Literature in Moscow. Between 1956 and 1958, some of 
these volumes were transferred to the Staatsbibliothek in Berlin in the German Democratic Republic. It was in 2003 that the Hungarian government took the great majority of the books back to Kismarton.

According to archival data from 1700 , there was a census of the books in the 17th century, described as "No. 194. Bibliothecae Excell(entissimi) D(omi)ni Pauli Esteras Palatini". This mysterious census, however, has never been found. The book census of 1756 was made at the time when the volumes of Palatine Pál Esterházy were transferred from Kismarton to the Franciscans. This census has at least two known parts. The title of the first part is Cathalogus Bibliothecae ad exigentiam Testamenti Principis condam Pauli Eszterházy Venerabili Conventui P. P. Franciscanorum ad S. Michaelem in Civitate Kismartonij Sub 16a et 17a Mensis Septembris Anni 1756 resignatorum et per manus traditorum. This part lists 901 volumes, divided into four subjects (Ecclesiastico-Historici, Ecclesiastici, Haeretici, and Scholastici). The books are also categorized according to their size (in regali, folio, quarto, octavo, sedemico). The title of the second part is Cathalogus Librorum In Arce, et Biblioteca Franko repositorum. It lists 551 volumes, divided into the following subjects: Juridici, Medici, Politici et Historici, Militares et geometrici, Historici de diversi animalibus, Libri Botanici, Canonici, Diversi antiqui oratores, Astrologici, Mathematici et Chymici de methalis, Geographici, Libri Topographici, categorized using the same sizes as the first part.

Monok and Zvara analyze the inventory compiled by the librarian János Hárich in 1937. They compare his book list with the list from 1756, showing that almost all the books contained in the first part of the 1756 list can be found on Hárich's list as well. However, the books included in the second part of the 1756 list cannot be found on Hárich's list. This leads the authors to the assumption that only the books located in Kismarton were given to the Franciscans, but not the ones from Fraknó.

Because of endless wars and the death of his sons, Pál Esterházy was forced to formulate several testaments. As Palatine Pál Esterházy's written wills about his library have survived the centuries, they are highly important for doing research into the Esterhasiana Biblioteca. In his 1664 testament, he declared that he wanted to leave his collection to the Franciscans. Subsequently, in his last testament of 1668, he named the library Esterhasiana Biblioteca.

The rest of Monok and Zvara's book is a catalog of the books of the Esterhasiana Biblioteca. It is organized according to the family members' collections. First, we have the list of the father Miklós Esterházy's (1583-1645) 62 books, followed by brother István Esterházy’s (1616-1641), the other brother László Esterházy’s (16261652) and Palatine Pál Eszterházy's items. This is followed by a summary of the 1756 census, which also belongs to Pál Esterházy’s 1452 volumes. The next chapter shows the 966 volumes that are not mentioned in the census of 1756. Another chapter deals 
with archival sources which refer to the library's history and stocks. The following chapter introduces the books and other writings of Pál Esterházy's descendants. This section includes 72 volumes. The last chapter is about the books of the priest Francesco Orsolini, who donated his collection to Pál Esterházy.

Despite the abundant material in the present publication, there are limitations to researching this huge collection. For instance, the 1700 census of the books is missing. As we learn from Monok and Zvara, the most detailed census was only created in 1756, after the death of Pál Esterházy. As the authors convincingly argue, the Esterházy library is an unparalleled collection for historians. The undertaking gives us access to all the information that we need to reconstruct this rich aristocratic library, including most of their booklists, testaments, and invoices. 